\title{
Measuring Pediatric Physical Function
}

\author{
Nancy L. Young, B.Sc.P.T., M.Sc., and James G. Wright, M.D., M.P.H., F.R.C.S.C. \\ Division of Orthopaedic Surgery and Clinical Epidemiology Unit, The Hospital for Sick Children, \\ Toromo, Ontario, Canado
}

Summary: Most pediatric orthopaedic interventions are intended to improve or preserve physical function, yet their outcomes have been assessed using primarily surrogate measures (e.g., radiographic indices) that may not accurately represent patients' function. Physical function may be more appropriately measured with activity-based scales, but these have been infrequently applied in surgical studies. The purpose of this study was to identify existing activity-based physical-function scales appropriate for pediatric orthopaedics, to present criteria useful for scale selection, and to discuss the special problems of measuring physical function in children. Twenty-one scales relevant to pediatric orthopaedics are described according to their target population, purpose, method of administration, content, and quality of standardization. These scales have been further classified according to a new taxonomy. The unique aspects of measuring physical function in children are discussed and include the effect of age and development, method of reporting, and question formats. Standardized measures of physical function based on physical-activity ability exist and should be used more frequently to assess pediatric orthopaedic interventions. Key Words: Measurement-OrthopaedicsOutcome assessment-Physical function.
Most pediatric orthopaedics treatment strategies are intended either to reduce existing physical disability [which has been defined as limitation in physical activity (65)] or to prevent future physical disability. Orthopaedic surgeons, however, have relied primarily on surrogate measures of physical function (e.g., range of motion and radiographic measurement) to assess the effectiveness of interventions. Surrogate measures are popular because they are easy to use, bear immediate relevance, and appear to be reliable. However, surrogate measures are not necessarily reliable (69), and more important, may not accurately represent changes in physical disability [e.g., despite radiographic curve correction in children with spina bifida, walking ability may decrease (40)]. Thus, although surrogate measures may be important in day-to-day clinical management, physical-function measures based on activities are arguably the most cogent outcomes of orthopaedic interventions.

Many activity-based physical-function scales capable of assessing the effects of clinical management have been developed in the rehabilitation field but have not been widely used by orthopaedic sur-

Address correspondence and reprint requests to Dr. J. Wright, Division of Orthopaedic Surgery and Clinical Epidemiology Unil, The Hospital for Sick Children, 555 University Avenue, Toronlo, Ontario, Canada MSG IX8.

Dr. J. Wright is the recipient of a Medical Research Council Scholarship. geons. Surgeons' infrequent use of such scales may be attributed to a lack of awareness of the existence of appropriate scales, difficulty obtaining scales, or unfamiliarity with the factors to be considered in selecting scales. In addition, because measurement of pediatric function has many special problems, such as the impact of growth and development, which few of the existing scales have completely addressed, surgeons may have deemed these scales inadequate for inclusion in clinical practice or research.

The purpose of this article is to aid surgeons in using activity-based measures by (a) cataloguing activity-based pediatric physical-function measures with direct application to pediatric orthopaedic practice; (b) explaining the options relevant to selection of appropriate scales; and (c) discussing some of the special problems of measuring physical function in pediatrics.

Physical function is defined in this article as the ability to use the musculoskeletal system to interact with the environment in a purposeful way for the performance of activities of daily living, mobility (e.g., manual dexterity, transfers, ambulation), and leisure activities $(16,42)$. Physical function is a distinct subcomponent of more global health measures such as functional status (16), health status $(1,42$, $52,56)$, and quality of life $(42,63)$. Because of the nature of orthopaedic interventions, the physicalfunction components of patients' status is the most 
likely to be affected and therefore is the focus of this article.

Standardization refers to the reliability, validity, and the responsiveness or discriminative ability of a measure. Reliability (reproducibility or consistency) is the degree to which the scale will yield similar answers when the measure is repeated $(60)$. Validity (or accuracy) is the extent to which the scale measures what it is intended to measure. Scales intended to evaluate change must also be able to detect clinically important change, which is termed responsiveness (or sensitivity). Scales intended to measure patients' status must be able to classify subjects correctly, which is termed discrimination and is quantified in terms of specificity and sensitivity (51).

\section{METHODS}

Physical-function measures were identified for review from three sources: a computerized literature search, the experience and resources of authors and colleagues, and the reference lists of publications identified using the first two strategies. The computer searches were conducted using the MEDLINE Index for the years 1984 to March 1993 and the allied health literature from 1984 to February 1992.

Scales were included in the review if the primary intent of the scale was to quantify activity-based physical function. Scales were excluded if they were developed for adult populations without specific documentation of pediatric application or were developmental milestone inventories (assuming a "normal" developmental sequence). Developmental scales have been extensively reviewed elsewhere $(8,12-14,20-22,27,43,44,58,61,62)$; however, one example has been included in the Appendix to promote an understanding of where these scales fit into the taxonomy.

\section{RESULTS}

The literature review identified 147 articles. The vast majority of the scales focused on developmental assessment (e.g., Hughes Basic Gross Motor Assessment), psychiatric or behavioral assessment (Child Behavior Check List), and intellectual aptitude (Weschler Scales, Illinois Test of Psycholinguistic Abilities), as has been previously reported (32). Twenty-one scales relevant to pediatric orthopaedics remained after exclusions: 13 were developed primarily for a pediatric population; four are adult scales modified for a pediatric population; and four are adult scales that have not been modified for children but have been used to measure pediatric physical function. These 21 scales are presented in the Appendix; however, the Appendix is not expected to be exhaustive.

For ease of use, the Appendix is subdivided into three sections: scales for children with neurological impairments, scales for children with arthritis, and scales that are not specific to any disease (also called generic scales). Within each section, the scales are listed according to a taxonomic classification. Column 1 lists names of the scales and provides references intended to assist the reader in the further investigation of pertinent scales. In several cases, a publication of the original scale development was not found; thus, the reference cited may be not the original author but a secondary source that presents a sufficient degree of detail for those interested in pursuing this scale further. Columns 2 to 7 are intended to aid surgeons in choosing among the available scales by describing the scales according to criteria that should be considered in the selection of appropriate scales and are described in detail in the following paragraphs.

\section{Purpose of the measure}

Column 2 discusses the intended use of the measure. Scales may be discriminative (distinguish between groups of patients), evaluative (detect change), or predictive (forecast the results of subsequent evaluations) (28). In clinical practice, surgeons are most often interested in evaluating the effect of interventions and thus predominantly seek evaluative scales. A scale developed for one purpose is not necessarily valid if used for a different purpose or population.

\section{Domains, format, and scoring}

Column 3 lists the functional domains that the scale covers, the format of the questions (e.g., visual analog or categorical), and how the questions are scored and aggregated. In some instances, full information was not available.

\section{Population}

Column 4 describes the population(s) on which the scale has been applied. Note that a scale's discriminative ability may be specific to the age or disease group for which it was developed. The measure must also be capable of scoring the full range of ability and disability expected in the study population.

\section{Method of administration}

Column 5 describes the details of administering the measure, including by whom (e.g., clinician or self-administered), how (e.g., observation or interview), to whom (e.g., child, parent, or proxy reporter), and the time and special equipment requirements.

\section{Standardization of the measure}

Column 6 contains details of the published reliability, validity, and responsiveness testing of the scales. The specifics of each scale's standardization testing can be found in the references cited in the Appendix and should be reviewed before selecting a scale $(9,46,60,68,69)$. One must seek a scale that offers sufficient standardization, bearing in mind 
that few, if any, scales have been completely standardized and that use of untested or inappropriate outcome variables will decrease the likelihood of detecting clinically important differences.

\section{Taxonomic classification}

Column 7 classifies the scales according to a new taxonomy (organizational framework), and the classification number is recorded in brackets in the Appendix. The taxonomy was created to simplify functional scale selection for surgeons and clinical researchers and is shown in Table 1. Under the taxonomy, scales are first classified by whether they are direct or indirect measures and then as capability or performance measures.

Direct measures are scored on the basis of personal observation of an activity or behavior. Indirect measures are scored on the basis of reported activity or behavior. Capability measures assess what the child can do. Performance measures assess what the child does do. Finally, indirect measures are further subdivided according to method of administration into self-report scales and interviewer-administered scales.

Examples of physical-function measures of each of the four main types are as follows. The playperformance scale (31), which requires that a clinician directly observe skills the child uses spontaneously in a normal play environment, is a directperformance measure (1.1). Clinical gait assessment requires a clinician's direct observation of what the child is able to do when it is demanded of him/her, and thus is a direct-capability measure (1.2). The Klein-Bell ADL scale is an indirect-performance measure, because it is scored based on report of previously observed spontaneous activity in a normal environmental context (2.1). Finally, surveys of what the child can do under hypothetical circumstances (often ideal circumstances) are indirectcapability measures $(2.2)$.

Direct methods may be considered more valid because they eliminate the biases of the reporter but may be sensitive to environmental changes and are rarely practical. Indirect methods offer enhanced feasibility, may have greater consistency of administration, and if self-administered, eliminate inter-

TABLE 1. Physical function measure taxonom ${ }^{\prime \prime}$

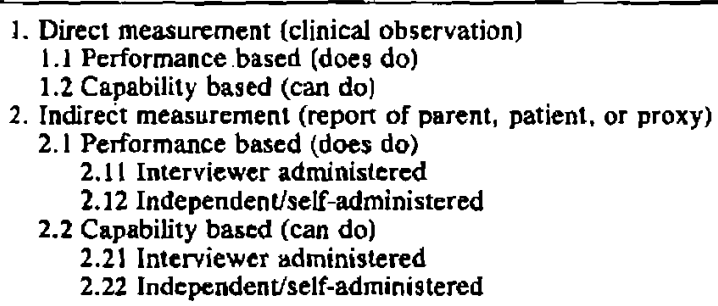

a Scales must be selected on the basis of their purpose and population. It was not feasible to put this into the taxonomy, as there is considerable overlap in purposes and populations. viewer bias. The difficulties inherent in self-report measures include uncertain comprehension or interpretation of the questions and response bias (\$9).

Capability measures have the advantage of potentially measuring all children in a consistent setting and being able to determine their best ability, but findings may not relate to their community function. Performance measures may better reflect their usual physical function by taking into account the child's usual social, environmental, and emotional settings, but improvement in performance may lag behind improvement in physiologic parameters and capability (e.g., a child may have the required range of motion to climb stairs and be capable but not yet perform the activity at school).

\section{DISCUSSION}

Physical-function measures are infrequently used by pediatric orthopaedists, possibly because of lack of awareness of existing scales, limited availability of the scales, difficulties in making appropriate selections, or because of the special problems inherent in the measurement of pediatric function. The identification and description of 21 scales that are potentially appropriate for pediatric orthopaedics attempt to address the first two obstacles. We hope the taxonomy presented in this article and the discussion of criteria for scale selection will aid surgeons in choosing among the available scales. Finally, the special challenges of measuring physical function in children must be addressed. Clinical application of physical-function scales should offer substantial benefits to research, provided there is some recognition of the effects of age, growth and development, the impact of the parent in reporting, and the framing of questions and response options.

\section{Age, growth, and development}

Prime considerations when evaluating the appropriateness of a pediatric scale for a specific population are the age for which the scale is applicable and the effect of development on sequential scores. Due to development, age has a distinct impact on ability to perform certain activities and on their relative importance. For example, tricycle riding is an important part of physical function at age 4 but not at age 8 , even though the motor skills required are still present.

At least two methods may accommodate for the effects of age. First, a comprehensive scale may be developed that covers physical function across al] age groups, such as the Rand Health Insurance Scale. This method is simple because only one scale is required for all children, but it may not be responsive to clinically important change. A variation of this method is to have a single scale but correct for age or stage of development by dividing the child's score by the maximum potential score for the child's specific age. For example, a 4-year-old might have a maximum score of 100 points, whereas 
on the same scale, a 5 -year-old might have a maximum of 120 because of advanced motor skill level. If a child scores 80 at age 4 , has surgery, and subsequently scores 96 at age 5 (both standardized scores are equal to $80 \%$ of expected), then no improvement can be attributed to the intervention beyond that which would have occurred with development. (Note, however, that the absence of a decline may be a clinically important finding indicative of success.) The process of age-adjusted scores requires normative data on the populations in question, and expected scores for disabled children are rarely available.

The second option is to use scales that are appropriate for limited age groups. This, however, requires multiple scales to accommodate various age groupings and makes measuring the effect of an intervention in children who cross over into a new age category during the trial very difficult. Thus agespecific scales are not recommended unless a translation between scales for different age groups has been clearly determined.

\section{Self, parent, and proxy report}

If the decision has been made to evaluate physical function indirectly, then the source of information must be selected: child, parent, or a proxy. When the focus of the intervention and research is the child, then the child should be the source of information. Parent report is required for patients whose communicative capacity is impaired by age, illness, or cognitive ability. Alternatively, proxy report can be used and may be advantageous when strong parental bias is suspected.

\section{Context}

The environmental conditions are particularly important when measuring physical function because they define whether capability or performance is being measured and affect the outcome (e.g., the degree of motivation, environinental distractions, and the presence of parents may significantly affect children's physical function). Additionally, physical function can be measured in multiple ways depending on the wording of the questions. Questions may ask about quality or quantity of function, each potentially yielding a different outcome. For exampie, physical function can be measured on a scale of independence, which can be affected by physical function, availability of supports, and willingness to accept assistance. The social construction of childhood is such that most children have readily available supports and may also be willing to accept assistance; therefore, independence measures may overestimate children's disability. Thus physicalfunction measures should not be adopted without consideration of contextual issues. Children's ability to comprehend certain question formats (such as visual analog scales) may also change as a function of age and requires consideration.

In summary, this article has addressed the prob- lems of availability, difficulties in selecting appropriate measures, and conceptual and methodological issues unique to measuring physical function in children. Appropriate scales can be selected using the references, standards, and taxonomy provided. Clinicians are encouraged to include activity-based function outcome measures in clinical and research practice, provided that they evaluate the existing scales carefully with regard to population, purpose, and standardization.

Future research will be required to determine the relationship between performance and capability, the agreement between parents and children, and the preferred context to measure physical function. These issues do not have a single correct answer, but none of the difficulties precludes the use of these activity-based measures. Finally, because orthopaedic interventions are intended to improve (or maintain) function, evaluations of surgical therapy should include measures of physical function, which can then be interpreted on the basis of clinical expectations.

\section{REFERENCES}

1. Bergnes M, Rothman ML. Health status measures: an overview and guide for selection. Annu Rev Publir Healih 1987;
8:191-210.

2. Buyce W, Gowland C, Russell D, Goldsmith C, Rosenbaum $P$, Plews $N$, Lane $M$. Consensus methodology in the development and content validation of a gross motor performance measure. Physiother Can 1993:45(2):94-100.

3. Boyce WF, Gowland C, Hardy S, Rosenbaum PL, Lane M, Plews N, Goldsmith C, Russell DJ. Development of a quajity-of-movement meusure for children with cerebral palsy. Phys Ther 1991;71(11):820-32.

4. Cadman D, Boyle MH, Offord DR, Szatmari P, Rae-Grant NI, Crawford J, Boyles J. Chronic illness and functional limitation in Ontario children: findings of the Ontario child health study. Can Med Assoc J 1986;135:761-7.

5. Coulton CJ, Zborowsky E, Lipton J, Newman AJ. Assessment of the reliability and validity of the Arthritjs Impact Messurement scales for children with juvenile arthritis. Arthritis Rheum 1987;30:819-24.

6. Eisen M, Donald CA, Ware JE, Brook RH. Conceptualization and measurement of health for children in the health insurance study. Report Number R-2313-HEW. Santa Monica, CA: Rand Corporation, 1980.

7. Eisen $M$, Ware JE, Donald D. Mersuring components of children's health status. Med Care 1979;17:902-21.

8. Ellison PH, Browning CA, Larson B, Denny J. Development of a scoring system for the Milani-Comparetti and Gidoni method of assessing neurologic abnormality in infancy. Phys Ther 1983;63:1414-23.

9. Feinstein AR. Clinimetrics. New Haven: Yale University Press, 1987.

10. Feldman AB, Haley SM, Coryell J. Concurrent and construct validity of the Pediatric Evaluation of Disability Inventory. Phys Ther 1990;70:602-10.

11. Fife SE, Roxborough LA, Armstrong RW, Harris SR, Gregson JL. Field D. Development of a clinical measure of postural control for assessment of adaptive seating in children with neuromotor disabilities. Phys Ther 1991;71:981-93.

12. Gans BM, Haley SM, Hallenborg SC, Mann N, Inacio CA, Fass RM. Description and interobserver reliability of the Tufts Assessment of Motor Performance. Am J Phys Med Rehabil 1989;67:202-10.

13. Gesell Institute of Human Development. The Gesell Pre- 
school Test for evaluating motor, udaptive, language, and personal-social behavior in chlldren ages $2^{1 / 2}$ to 6 . New $\mathrm{Ha}-$ ven, CT: The Gesell Institute of Human Development, 1979.

14. Gowland C. King G, King S, Law M, Letts L, MacKinnon L, Rosenbaum P. Russell D. Review of selected measures in neurodevelopmental retiabilitation (a rational appraach for selecring clinical measures). Research Repon, 91-2. Hamilton, Ontario: Neurodevelopmental Clinical Research Unit Chedoke-McMaster Hospitals, 1991.

15. Granger CV, Hamilton BB, Kayton R. Guide for use of the Functional Independence Measure for Children (WeeFIM). New York: Research Foundation, State Unjversity of New York, 1989.

16. Haley SM, Coster W, Ludlow LH. Pediatric functional outcome measures. Phys Med Rehabil Clin North Am 1991;2 (4):689-723

17. Huley SM, Coster WJ, Fans RM. A content validity study of the Pediatric Evaluation of Disability Inventory. Pediatr Phys Ther 1991;3:177-84.

18. Haley SM, Coster WJ, Ludlow LH, Haltiwanger JT, Andrellaw PJ. Pediatric Evaluation of Disability Inventory (PEDI). Development, standardization and administration manual. Boston, MA: New England Medical Center Hospitals, 1992 .

19. Haley SM, Ludlow LH, Gans BM, Faas RM, Inacio CA. Tufts assessment of motor performance: an empirical approach to identifying motor performance caleguries. Arch Phys Med Rehabil 1991;72:359-66.

20. Haywood KM. Life span motor developmens. Champaign, IL: Human Kinetics Publishers, 1986.

21. Howe S, Levinson J, Shear E, Hartner S, McGirr G, Schulte $M$, Lovell D. Development of a disability measurement tool for juvenile rheumatoid arthritis. Arthritis Rheum 1991;34: 873-80.

22. Hughes JE. Hughes Basic Gross Motor Assessment (manual). Yonkers, NY: GE Miller, 1979

23. Hutchinson TA, Boyd NF, Feinstein AR, Gonda A, Hollomby D, Rowat B. Scientific problems in clinical scales, as demonstrated in the Kamofsky Index of Performance Status. J Chron Dis 1979;32:661-6.

24. Kaplan RM, Bush JW, Berry CC. The reliability, stability, and generalizability of a health status index. Proce dings of the Social Statistics Sections. Alexandria, VA: American Statistical Assnciation, 1978:704-9.

25. Karnofsky DA, Burchenall JH. The clinical evaluation of chemotherapeutic agents in cancer. In: McLeod CM, ed. Evaluation of chemotherapeutic agents. New York: Columbia University Press, 1949:190-204.

26. Kicklighter RH, Richmond BO. Children's Adaptive Behavior Scule-revised. Atlanta, GA: Humanics Lid., 1983.

27. King-Thomas L, Hacker BJ. A therapist's guide to pediatric assessment. Toronto, Ontario: Little. Brown, 1987.

28. Kirshner B, Guyatt G. A methodological framework for assessing health indices. $J$ Chron Dis 1985;38:27-36.

29. Klein RM, Bell B. The Klein-Bell ADL Scale manual. Seattle. WA: University of Washington Medical School, Health Sciences Resource Center/SB-56, 1979.

30. Klein RM, Bell B. Self-care skills: behavioural measurement with the Kleir-Bell ADL scale. Arch Phys Med Rehabil 1982;63:335-8.

31. Lansky LL, List MA, Lansky SB, Cohen ME, Sinks LF Towand the development of a Play Performance Scale for Children (PPSC), Cancer 1985;56:I837-40.

32. Lansky SB, List MA, Lansky L, Ritter-Sterr C, Miller DR. The measurement of performance in childhood cancer patients. Cancer 1987;60:1651-6.

33. Law M. Copy of the Klein-Bell ADL Scale with age norms applied. Hamilton, Ontario: McMaster University, 1992.

34. Law M, Baptiste S, Darswell-Opzoomer A, McColl MA. Polatajiko H. Pollock N. The Canadian Occupatiunal Performance Measure. Canada: CAOT Publications, 1991.

35. Law M, Baptiste S, McColl MA, Opzoomer A, Polatajiko H,
Pollock N. The Canadian Occupational Performance Measure: an outcome measure for occupational therapy. Can $J$ Occup Ther 1990;57:82-8.

36. Law M, Letts $L$. A critical review of scales of activities of daily living. Am $J$ Occup Ther 1989:43:522-8.

37. Law M. Usher P. Validation of the Klein-Bell Activities of Daily Living Scale for chijdren. Can J Occup Ther 1988;55: 63-8.

38. Lovell DH, Howe S, Shear E, Hartner S, McGirr G, Schulte $M$, Levinson J. Development of a disability measurement tool for juvenile rheumatoid arthritis. Arthritis Rheum 1989 ; 32:1390-5.

39. Mahoney FI, Barthel DW. Functional evaluation: the Barthel Index. Maryland Staie Med J 1965;14:61-5.

40. Mazur J, Menelaus MB, Dickens RV, Diog WG. Efficacy of surgical management for scoliosis in myelomeningocele: correction of deformity and alleration of functional status. Pediatr Orthop 1986:6:568-75.

41. McCabe MA, Granger CV. Content validity of a pediatric functional independence measure. Appl Nur, Res 1990;3: 120-2.

42. Meenan RF. Health status assessment in pediatric rheumatology. Rheum Dis Clin North Am 1987;13:133-40.

43. Milani-Comparetti A, Gidoni AE. Routine developmental examination in normal and retarded children. Dev Med Child Neurol 1967;9:631-8.

44. Miller LJ. Miller Assessment for Pre-schoolers (manual) Englewood, $\mathrm{CO}$ : The Foundation for Knowledge in Development, 1982.

45. Milstein JM, Cohen ME, Sinks LF, The influence and reliability of neurologic assessment and Karnofsky performance score on prognosis. Cancer 1985;56:1834-6.

46. Nunnally JC. Psychometric theory. New York: McGrawHill, 1978.

47. Orenstein DM, Nixon PA, Ross EA, Kaplan RM. The qualjty of well-being in cystic fibrosis. Chest 1989:95:344-7.

48. Research Foundation-State University of New York. Guide for use of the Uniform Data Set for Medical Rehubilitation including the Functional Independence Measure for Children (WeeF/M). Buffalo, NY: State Unjversity of New York, 1991.

49. Russell D, Rosenbsum P. Gowland C, Hardy S, Lane M, Plews N. McGavin H, Cadman D, Jarvis S. Gross Motor Function Measure manual. Hamilton, Ontario, Canada: Gross Motor Measures Group, 1990.

50. Russell DJ, Rosenbaum PL, Cadman DT, Gowland C, Jarvis $S$. The Gross Motor Function Measure: megns to evaluate the effects of physical therapy. Dev Med Child Neurol 1989: 31:341-52.

51. Sackett DL, Haynes RB, Tugwell P. Clinical epidemiolngy. A basic science for clinical medicine. Toronto: Little, Brown, 1985

52. Schipper H. Levitt M. Measuring quality of life: risks and benefits. Cancer Treat Rep 1985;69:1115-23.

53. Singh G. Copy of Childhood Health Assessment Questionnaire and guidelines. Pulo Alto: Stanford University School of Medicine, 1992.

54. Singh G, Brown B, Arhreya B, Goldsmith D, Rettig P, Block $D$, Fries J. Functional slatus in juvenile rheumatoid arthritis: sensitivity to change of the childhood health assessment questionnaire [Abstract]. Arrhritis Rheum 1990;33S:SIS.

55. Sparrow S, Balla D, Cicchetti D. Vineland Adaptive Behavior Scales, interview' edition: survey form manual. Circle Pines, MN: American Guidance Service, 1984.

56. Spitzer WO. State of science 1986: quality of life and functional status as target variables for research. $J$ Chron Dis 1987:40:465-71.

57. Stee] KO, Glover JE, Spasoff RA. The motor control assessment: an instrument to measure motor control in physically disabled children. Arch Phys Med Rehabil 1991:72:549-53.

58. Stower S, Huber CJ. Developmental and screening tests. In: King-Thomas L, Hacker BJ, ed. A rherapist's guide to pediatric assessmenr. Boston: Little. Brown, 1987:43-142. 
59. Streiner DL, Norman GR. Biases in responding. In: Streiner DL, Norman GR, ed. Heallh measurement scales: a pracstcal gulde to their development and use. New York: Oxford University Press, 1989:54-66.

60. Striner DL, Norman GR. Healih meusuremens scales: a practical gulde to their development and use. New York: Oxford University Press, 1989.

61. Stuberg WA. White PJ. Miedaner JA, Dehne PR. Item reliability of the Milani-Comparesti Motor Development Screening Test. Phy,s Ther 1989;69:328-35.

62. Van Wendt $L$, Svanberg $K$, Clausen $M$, Janlert U, Back !, Therell M. Screening for delayed motor development in preschool age children using Stat1-Moyes-Henderson's Test of Motor Impairment. Physiother Can 1985;37:350-3.

63. Ware JE. Standards for validating health measures: definjtion and content. J Chron Dis 1987;40:473-80.

64. Wesson DE. Williams J1, Spence LJ, Filler RM, Armsirong
PF, Pearl RH. Functional outcome in pediatric trauma. $J$ Trauma 1989;2929:589-92.

65. World Health Organization. International classification of impairments, disabilities, and handicaps. Geneva: World Health Organization, 1980.

66. Wright FV, Law M, Goldsmith C, Dent P. Development of a self-report functional status index for children and teens with juvenile arthritis (JA). Physiother Can 1991;43:11 (conference insert).

67. Wright FV, Longo-Kimber J, Law M, Goldsmith C. Dent P. A functional status index for juyenile arthritis (JA). Physiother Can 1992;44:6 (conference insert).

68. Wright JG, Feinstein AR. A comparative contrast of clinimetric and psychometric methods for constructing indexes and rating scales. J Clin Epidemiol 1992;45:1201-18.

69. Wright JG, Feinstein AR. Improving the reliability of orthopaedic measurements. J Bone Joint Surg [Br] 1992;74:287-91.

APPENDIX

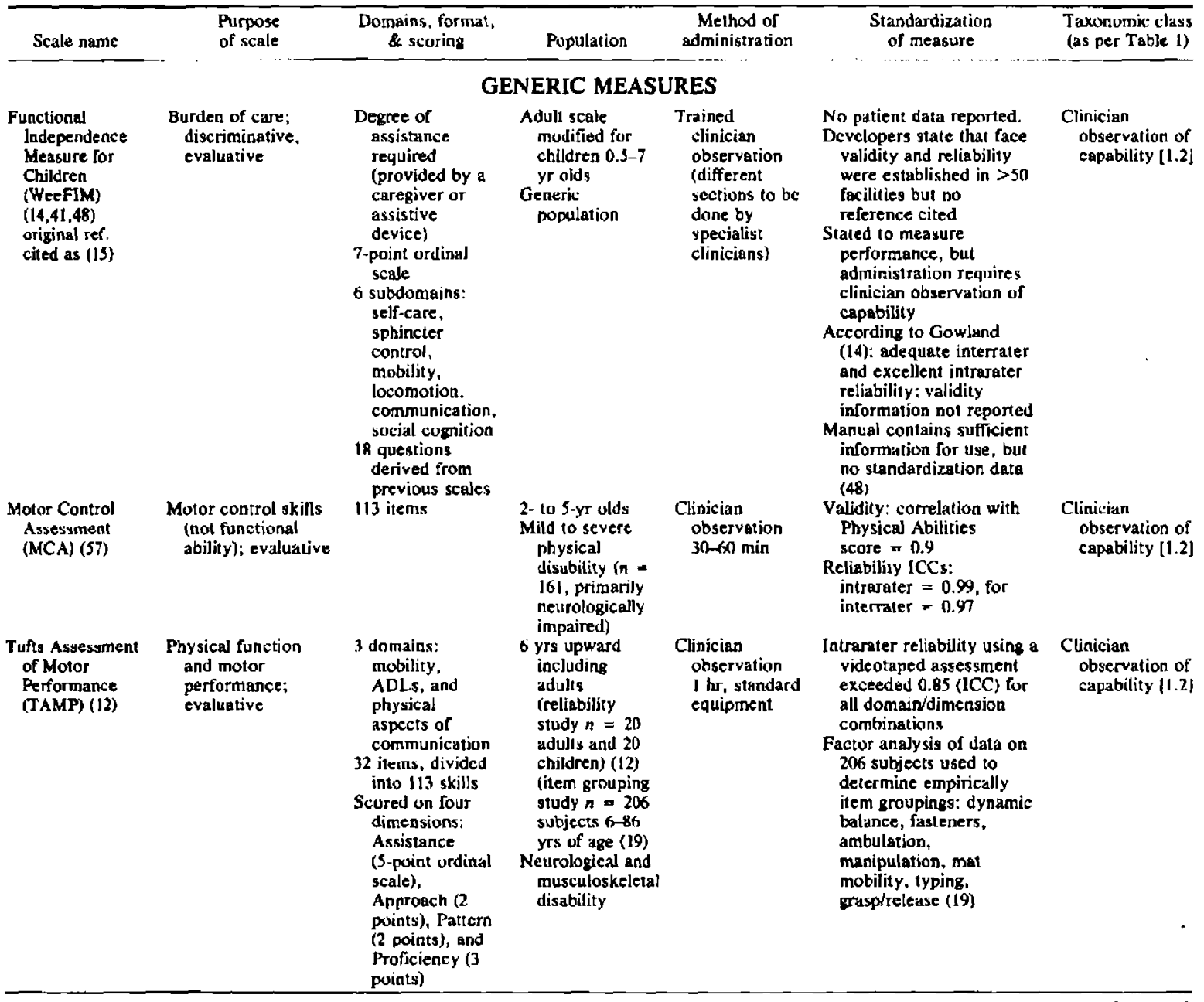


APPENDIX (Continued)

\begin{tabular}{|c|c|c|c|c|c|c|}
\hline Scale name & $\begin{array}{l}\text { Purpose } \\
\text { of scale }\end{array}$ & $\begin{array}{l}\text { Domains, format, } \\
\text { \& scoring }\end{array}$ & Population & $\begin{array}{l}\text { Method of } \\
\text { administration }\end{array}$ & $\begin{array}{l}\text { Standardization } \\
\text { of measuse }\end{array}$ & $\begin{array}{l}\text { Taxonomic class } \\
\text { (as per Table 1) }\end{array}$ \\
\hline $\begin{array}{l}\text { Klein-Bell ADL } \\
\text { scale (14,33, } \\
\text { 36,37); original } \\
\text { adult Bcale cited } \\
\text { as }(29,30)\end{array}$ & $\begin{array}{l}\text { ADL function; } \\
\text { evaluative. } \\
\text { discriminative }\end{array}$ & $\begin{array}{l}6 \text { domains: } \\
\text { dressing; } \\
\text { bathing/hygiene. } \\
\text { elimination, } \\
\text { functional } \\
\text { mobility, } \\
\text { eating, } \\
\text { emergency } \\
\text { communication } \\
170 \text { skills items } \\
\text { Scores: able, } \\
\text { unable, N/A } \\
\text { Includes age } \\
\text { norms beside } \\
\text { each question } \\
\text { More upper } \\
\text { extremity } \\
\text { function iterts } \\
\text { than lower }\end{array}$ & $\begin{array}{l}\text { All ages } \\
\text { Test propulation } \\
10 \mathrm{CP} \text { and } 10 \\
\text { normals }\end{array}$ & $\begin{array}{l}\text { Clinician } \\
\text { observation } \\
\sim 1 \text { h to } \\
\text { administer all } \\
\text { items }\end{array}$ & $\begin{array}{l}\text { Validicy: discriminated } \\
\text { berween normal and CP } \\
\text { subjects p<0.00] } \\
\text { Reliability for } S \text { children } \\
\text { interrater ICC }=0.99 \text {, } \\
\text { test-netest ICC }-0.98 \\
\text { Responsiveness: ereater } \\
\text { change in normals than } \\
C P(p=0.08) \text { and agree- } \\
\text { ment with parental } \\
\text { ratings of change gave } \\
\text { currecled } k=0.77 \\
\text { According to Gow land } \\
\text { (14): excellent content } \\
\text { validity and reliability, } \\
\text { adequate construct } \\
\text { validity and } \\
\text { responsiveness } \\
\text { These concluslons were } \\
\text { supported by Law (36) }\end{array}$ & $\begin{array}{l}\text { Clinician } \\
\text { observation of } \\
\text { capability [1.2] }\end{array}$ \\
\hline $\begin{array}{l}\text { Barthel lndex } \\
(14,36) \text {. Original } \\
\text { ref. cited as } \\
\text { (39) }\end{array}$ & $\begin{array}{l}\text { Activities of daily } \\
\text { living; } \\
\text { discriminative. } \\
\text { predictive, } \\
\text { evaluative }\end{array}$ & $\begin{array}{l}\text { ADL:s } \\
\text { Ordinal scale }\end{array}$ & $\begin{array}{l}\text { Applied to adult } \\
\text { and adolescent } \\
\text { chronically } \\
\text { disabled } \\
\text { patients }\end{array}$ & $\begin{array}{l}\text { Expert clinician } \\
\text { observation } \\
1 \text { h to complete }\end{array}$ & $\begin{array}{l}\text { According to Law (36): } \\
\text { Excellent content validity, } \\
\text { construct validity, inter- } \\
\text { and intrarater reliability } \\
\text { good responsiveness } \\
\text { Poor manual and internal } \\
\text { consistency } \\
\text { According to Gowland } \\
\text { (14): } \\
\text { Adequste content validity, } \\
\text { criterion validity, inter- } \\
\text { and intrarater reliability } \\
\text { Poor manual } \\
\text { No normative data }\end{array}$ & $\begin{array}{l}\text { Clinician } \\
\text { observation of } \\
\text { capability [1.2] }\end{array}$ \\
\hline $\begin{array}{l}\text { Karnofsky Scale } \\
(23,25,45)\end{array}$ & $\begin{array}{l}\text { Global rating of } \\
\text { physical capacity; } \\
\text { evaluative, } \\
\text { predictive }\end{array}$ & $\begin{array}{l}\text { Based primarily } \\
\text { on mobility } \\
\text { level } \\
\text { Scoring: 0-100 in } \\
\text { In-unit Guttman } \\
\text { intervals }\end{array}$ & $\begin{array}{l}\text { Undefined } \\
\text { cancer } \\
\text { population } \\
\text { (generally } \\
\text { poor } \\
\text { description of } \\
\text { samples) }\end{array}$ & $\begin{array}{l}\text { Physician } \\
\text { report } \\
2 \mathrm{~min}\end{array}$ & $\begin{array}{l}\text { Weak evidence for validity } \\
\text { demonstrated by } \\
\text { comparing measure with } \\
\text { other clinical criteria } \\
\text { Reliability: achieved } 29 \\
\text { and } 35 \% \text { agreement } \\
\text { between raters } \\
\text { Previous reviewers } \\
\text { concluded that the scale } \\
\text { is not apppropriate for } \\
\text { children, particularly } \\
\text { preschnolers, and that it } \\
\text { is unable to predict } \\
\text { recurrence in brain } \\
\text { tumor pediatric patients } \\
\text { (45) }\end{array}$ & $\begin{array}{l}\text { Physician report } \\
\text { of capability } \\
\text { [1.2] } \\
\text { Note: because of } \\
\text { the question } \\
\text { wording it is } \\
\text { possible that } \\
\text { performance } \\
\text { was reported } \\
\text { by some. }\end{array}$ \\
\hline $\begin{array}{l}\text { Vineland } \\
\text { Adaptive } \\
\text { Behavior Scales } \\
\text { (14). Oripinal } \\
\text { ref. cited as } \\
\text { (55) }\end{array}$ & $\begin{array}{l}\text { Developmental } \\
\text { Assessment Toul } \\
\text { Included as example } \\
\text { of developmental } \\
\text { scale classification }\end{array}$ & $\begin{array}{l}4 \text { domains: } \\
\text { communjcation, } \\
\text { daily living } \\
\text { skills, } \\
\text { socialization, } \\
\text { and motor skills } \\
\text { (impaiment) }\end{array}$ & $\begin{array}{l}\text { 0-18 yrs } \\
\text { Normutive data } \\
\text { based on a } \\
\text { large sample } \\
\text { of disabled } \\
\text { children }\end{array}$ & $\begin{array}{l}\text { Trained } \\
\text { clinician } \\
\text { interview of } \\
\text { parent } \\
20-90 \mathrm{~min}\end{array}$ & $\begin{array}{l}\text { Reliability and validity } \\
\text { reported by Gowland to } \\
\text { be excellent }\end{array}$ & $\begin{array}{l}\text { Interview of } \\
\text { parent } \\
\text { measure of } \\
\text { performance } \\
\text { [2.11] }\end{array}$ \\
\hline $\begin{array}{l}\text { Quality of } \\
\text { Well-being (47). } \\
\text { Original ref. } \\
\text { cited } \\
\text { as (24) }\end{array}$ & $\begin{array}{l}\text { Quality of life; } \\
\text { discriminative, } \\
\text { evaluative }\end{array}$ & $\begin{array}{l}3 \text { domains: } \\
\text { mobility (J-level } \\
\text { ordinul scale), } \\
\text { social activity } \\
\text { (5-level ordinal } \\
\text { scale), physical } \\
\text { activity (4-level } \\
\text { ordinal scale) } \\
\text { Scores weighted } \\
\text { according to } \\
\text { population } \\
\text { preferences } \\
\text { Similar to Rand } \\
\text { Health } \\
\text { Insurance Scale }\end{array}$ & $\begin{array}{l}\text { Adult tool } \\
\text { applied to } \\
\text { children } \\
25 \text { boys and } 19 \\
\text { dirls with CF } \\
\text { Ages 7-36, mean } \\
16.5 \pm 6.9 \text { yrs }\end{array}$ & $\begin{array}{l}\text { Interview } \\
\text { administered } \\
\text { to parents or } \\
\text { patient } \\
\text { depending on } \\
\text { age }\end{array}$ & $\begin{array}{l}\text { Moderate construct } \\
\text { validity assessed by } \\
\text { comparing QWB to } \\
\text { PFTs and exercise } \\
\text { tolerance: QW B/FEV, } \\
r=0.6 \\
\text { QWB/FEF } \\
\text { QWB/PEFR } r=0.4=0.5 \\
\text { QWBNO } r=0.4 \\
\text { mex } r=0.6\end{array}$ & $\begin{array}{l}\text { laterview-administered } \\
\text { measure of } \\
\text { performance } \\
{[2.11]}\end{array}$ \\
\hline
\end{tabular}


APPENDIX (Continued)

\begin{tabular}{|c|c|c|c|c|c|c|}
\hline Scale name & $\begin{array}{l}\text { Purpose } \\
\text { of scale }\end{array}$ & $\begin{array}{l}\text { Domains, format, } \\
\text { scoring }\end{array}$ & Population & $\begin{array}{l}\text { Method of } \\
\text { administration }\end{array}$ & $\begin{array}{l}\text { Standardization } \\
\text { of measure }\end{array}$ & $\begin{array}{l}\text { Taxonomic class } \\
\text { (as per Table I) }\end{array}$ \\
\hline $\begin{array}{l}\text { Canadian } \\
\text { Occupational } \\
\text { Peformance } \\
\text { Messure } \\
\text { (COMP) } \\
(14,34.35)\end{array}$ & $\begin{array}{l}\text { Evuluative } \\
\text { Subjects generate } \\
\text { their own jtems } \\
\text { Useful for } \\
\text { comparison within } \\
\text { individual patients } \\
\text { rather than } \\
\text { between patients }\end{array}$ & $\begin{array}{l}\text { Domains: } \\
\text { seff-care, } \\
\text { productivity } \\
\text { and leisure } \\
\text { Dimensions: } \\
\text { importance of } \\
\text { activitics, level } \\
\text { of performance } \\
\text { \& satisfaction } \\
\text { with } \\
\text { perfortnance } \\
\text { Scoring: } \\
\text { 10-category } \\
\text { ordinal scales }\end{array}$ & $\begin{array}{l}\text { Not age specific } \\
\text { Develuped for } \\
\text { adults and } \\
\text { applied to } \\
\text { children }\end{array}$ & $\begin{array}{l}\text { Clinician } \\
\text { administ ered } \\
\text { ltems } \\
\text { spontaneously } \\
\text { elicited from } \\
\text { each patient } \\
\text { Interview of } \\
\text { parent or } \\
\text { child } \\
\text { Considers } \\
\text { environmental } \\
\text { demands }\end{array}$ & $\begin{array}{l}\text { No evidence of validity or } \\
\text { reliability included (14) }\end{array}$ & $\begin{array}{l}\text { Interview } \\
\text { measure of } \\
\text { capability and } \\
\text { performance } \\
{[2.11 \& 2.21]}\end{array}$ \\
\hline $\begin{array}{l}\text { Pediatric } \\
\text { Evaluatlon of } \\
\text { Disability } \\
\text { Inventory } \\
\text { (PEDI) } \\
\text { development } \\
\text { edition } \\
(10,17,18)\end{array}$ & $\begin{array}{l}\text { Physical Funclion \& } \\
\text { lndependence } \\
\text { Measure; } \\
\text { evaluative } \\
\text { Expert reviewers } \\
\text { preferred to class } \\
\text { the tool as } \\
\text { discriminative } \\
\text { rather than } \\
\text { evaluative (17) }\end{array}$ & $\begin{array}{l}\text { Domains: } \\
\text { self-case, } \\
\text { mobility, social } \\
\text { function } \\
\text { Scoring } \\
\text { dimensions: } \\
\text { functional } \\
\text { capability, } \\
\text { caregiver } \\
\text { assistance, } \\
\text { environmental } \\
\text { modifications } \\
\text { Scored } \\
\text { able/unable for } \\
\text { l97 functional } \\
\text { skill items, } 6 \\
\text { ordinal } \\
\text { responses for } \\
20 \text { caregiver } \\
\text { assistance } \\
\text { items, } 4 \\
\text { types of } \\
\text { environmental } \\
\text { modifications } \\
\text { for } 20 \text { jtems }\end{array}$ & $\begin{array}{l}\text { Chronically ill } \\
\text { and disabled } \\
\text { children } \\
0.5-7 \text { yrs old }\end{array}$ & $\begin{array}{l}\text { Parent report } \\
20 \text { min ta } 1 \text { h to } \\
\text { complete }\end{array}$ & $\begin{array}{l}\text { Concurrent validity: } \\
\text { moderately bigh } \\
\text { correlations with Battelle } \\
\text { Developmental } \\
\text { Inventory Screening Test } \\
\text { for self-care and mobility } \\
\text { domains but not socia! } \\
\text { function domains ( } 10 \text { ) } \\
\text { Significant differences } \\
\text { between normals and } \\
\text { disabled samples (10) } \\
\text { Content validity and } \\
\text { reliability studiex are } \\
\text { currently underway, but } \\
\text { unpublshed normative } \\
\text { data (sample of } 412 \text { ) not } \\
\text { yet published (10) } \\
\text { Manual (18) inciudes a } \\
\text { detuiled report of } \\
\text { standardization. which is } \\
\text { adequate in al) areas, } \\
\text { discussion of scaling } \\
\text { methods, describes } \\
\text { calculation of } \\
\text { standardized scores }\end{array}$ & $\begin{array}{l}\text { Parent report of } \\
\text { performance } \\
{[2.12]}\end{array}$ \\
\hline $\begin{array}{l}\text { Play Performance } \\
\text { Scale }(31,32)\end{array}$ & Play; cvuluative & $\begin{array}{l}\text { Concepts based } \\
\text { on Kamofsky"s } \\
\text { Scale } \\
\text { Based on active } \\
\text { play, quiel } \\
\text { play, degree of } \\
\text { physical } \\
\text { limitation. } \\
\text { degree of } \\
\text { independence } \\
\text { Scored 0-100 in } \\
\text { l0-print } \\
\text { increments }\end{array}$ & $\begin{array}{l}\text { l-16 yr olds } \\
\text { Brain tumors } \\
\text { In }-98 \\
\text { oncology } \\
\text { patients, } 8 \pm \\
4.71 \text { yrs of } \\
\text { agc; } 29 \\
\text { siblingss } \\
8.76 \pm 4.42 \\
\text { yrs: } 40 \\
\text { normals, } \\
8.59 \pm 4.98 \\
\text { yrs) (32) }\end{array}$ & $\begin{array}{l}\text { Parent report } \\
<5 \text { min to } \\
\text { complete }\end{array}$ & $\begin{array}{l}\text { Interrater reliability } \\
\text { (mother vs. father) } r= \\
0.71, n=41 \\
\text { Construct validity: } \\
\text { detected significant } \\
\text { difference between } \\
\text { patients and siblings, and } \\
\text { significantly related to } \\
\text { elobal measure of } \\
\text { performance from nurses } \\
\text { and reseachers }(r= \\
0.75 \text { and } r=0.92 \text {, } \\
\text { respectively) (32) }\end{array}$ & $\begin{array}{l}\text { Parent repor } \\
\text { measure of } \\
\text { performance } \\
{[2.12]}\end{array}$ \\
\hline $\begin{array}{l}\text { Rand Health } \\
\text { Insurance } \\
\text { Study Scale } \\
\text { (HIS) }(6,7)\end{array}$ & $\begin{array}{l}\text { Physical activity; } \\
\text { discriminative }\end{array}$ & $\begin{array}{l}4 \text { domains: } \\
\text { mobility, } \\
\text { physical } \\
\text { activity, mle } \\
\text { activity, and } \\
\text { self-care } \\
\text { Children's tool } \\
\text { similar to AIMS } \\
\text { (7) }\end{array}$ & $\begin{array}{l}\text { Agey } 0-13 \text { yrs } \\
(n=2,152 \\
\text { childres in } 6 \\
\text { U.S. cities) }(7) \\
\text { Ages } 4-16 \text { yrs } \\
(n=3,294 \\
\text { children in } \\
\text { Ontario) (4) } \\
\text { Healthy } \\
\text { populations } \\
\text { ( } n=156 \\
\text { pediatric } \\
\text { traumg } \\
\text { survivors age } \\
8.7 \pm 4.4)(64)\end{array}$ & $\begin{array}{l}\text { Researcher } \\
\text { administered } \\
\text { Parent report }\end{array}$ & $\begin{array}{l}\text { Consiruct validity: } \\
\text { comparison of HIS } \\
\text { classification of } \\
\text { able/disabled with } 11 \\
\text { other scales showtd } \\
\text { significant differences for } \\
\text { all } 11 \text { scales; however. } \\
\text { ectual differences were } \\
\text { small and the sample } \\
\text { large } \\
\text { Found a } 57 / 1,000 \\
\text { prevalence of disability } \\
\text { (4) } \\
\text { Wesson et al. found the } \\
\text { HIS not to be able to } \\
\text { discriminate severity in a } \\
\text { trauma population (64) } \\
\text { Administration manual (6) }\end{array}$ & $\begin{array}{l}\text { Parent report } \\
\text { measure of } \\
\text { performance } \\
{[2.12]}\end{array}$ \\
\hline
\end{tabular}


APPENDIX (Continued)

\begin{tabular}{|c|c|c|c|c|c|c|}
\hline Scale name & $\begin{array}{l}\text { Purpose } \\
\text { of scale }\end{array}$ & $\begin{array}{l}\text { Domains, format, } \\
\text { \& scoring }\end{array}$ & Population & $\begin{array}{l}\text { Method of } \\
\text { administration }\end{array}$ & $\begin{array}{c}\text { Standardization } \\
\text { of measure }\end{array}$ & $\begin{array}{l}\text { Taxonomic class } \\
\text { (as per Table 1) }\end{array}$ \\
\hline $\begin{array}{l}\text { Childhood Heslth } \\
\text { Assessment } \\
\text { Questionnaire } \\
\text { (CHAQ) }(53,54)\end{array}$ & $\begin{array}{l}\text { Functional status; } \\
\text { evaluate } \\
\text { functional status }\end{array}$ & $\begin{array}{l}8 \text { domains: } \\
\text { dressing } \\
\text { grouming, } \\
\text { arising, eating, } \\
\text { walking, } \\
\text { hygiene, reach, } \\
\text { grip. and } \\
\text { activities } \\
\text { 4-point ordinal } \\
\text { scale for each } \\
\text { item } \\
\text { Unusual method } \\
\text { of asgregation }\end{array}$ & $\begin{array}{l}\text { JRA }(n=62) \\
\text { I-19 ys olds } \\
\text { Derived from an } \\
\text { adult tool }\end{array}$ & $\begin{array}{l}\text { Panent or } \\
\text { patient } \\
\text { self-administered } \\
\text { 10 min }\end{array}$ & $\begin{array}{l}\text { No documentation of } \\
\text { validity or reliability in } \\
\text { children } \\
\text { Responsiveness: CHAQ } \\
\text { Was \& significant } \\
\text { predictor of parents" } \\
\text { global rating of change } \\
\text { < } 0.02 \\
\text { Report that "parents are } \\
\text { reliable proxy reporters } \\
\text { of their children's } \\
\text { functional status" but no } \\
\text { data or reference are } \\
\text { provided to support this }\end{array}$ & $\begin{array}{l}\text { Parent or } \\
\text { self-report of } \\
\text { capability } \\
{[2.22]}\end{array}$ \\
\hline \multicolumn{7}{|c|}{ DISEASE SPECIFIC-NEUROLOGICAL ${ }^{a}$} \\
\hline $\begin{array}{l}\text { Gross Mutor } \\
\text { Punction } \\
\text { Measure } \\
\text { (GMFM) } \\
(49,50)\end{array}$ & $\begin{array}{l}\text { Grose motor } \\
\text { abilities: } \\
\text { evaluative, } \\
\text { discriminative }\end{array}$ & $\begin{array}{l}\text { 85-88 irems } \\
\text { Gross motor skills } \\
\text { Assesses the } \\
\text { quantity of skill } \\
\text { capability not } \\
\text { quality } \\
\text { 4-point urdinal } \\
\text { scale per item } \\
\text { Iterns equally } \\
\text { weighted within } \\
\text { dimension } \\
\text { Domains: lying, } \\
\text { sitting, crawling } \\
\text { \& kneeling. } \\
\text { standing, and } \\
\text { walking-rurning- } \\
\text { jumping } \\
\text { Scoring clearly } \\
\text { described with } \\
\text { examples }\end{array}$ & $\begin{array}{l}\text { Cerebral paisy } \\
\text { (n- II ) and } \\
\text { acute head } \\
\text { injuries (n }= \\
25) \text { (contro! } \\
\text { subjects were } \\
34 \text { normals <5 } \\
\text { yrs old) }\end{array}$ & $\begin{array}{l}\text { Trained } \\
\text { clinician } \\
\text { observation } \\
\text { Highly } \\
\text { structured } \\
\text { assessment } \\
\text { Time estimated } \\
\text { at }>\text { i b }\end{array}$ & $\begin{array}{l}\text { Validity: moderate } \\
\text { correlations with } \\
\text { clinicians" judgments } \\
\text { Reliability: intrarater } \\
\text { correlations }>0.92 \text {, } \\
\text { interrater correlations } \\
>0.87 \\
\text { Responsiveness: significant } \\
\text { difference in scores of } \\
\text { subjects who h8d } \\
\text { changed and no } \\
\text { significant difference in } \\
\text { the scores of patients } \\
\text { whose parents rated } \\
\text { them as unchanged } \\
\text { Manual (49) includes a } \\
\text { detailed report of } \\
\text { standardization, which is } \\
\text { adequarc in all areas }\end{array}$ & $\begin{array}{l}\text { Clinician } \\
\text { observation of } \\
\text { capability [1.2] }\end{array}$ \\
\hline $\begin{array}{l}\text { Gross Motor } \\
\text { Performance } \\
\text { Measure } \\
\text { (GMPM) }(2.3)\end{array}$ & $\begin{array}{l}\text { Qualitative aspects } \\
\text { of gross motor } \\
\text { function: } \\
\text { evaluative }\end{array}$ & $\begin{array}{l}\text { Assesses the } \\
\text { quality of } \\
\text { capability } \\
\text { Domains: } \\
\text { alignment, } \\
\text { coordination, } \\
\text { dissociated } \\
\text { movement, } \\
\text { stability, weighe } \\
\text { shift } \\
\text { Impaiment }\end{array}$ & Cerebral pulsy & $\begin{array}{l}\text { Trained } \\
\text { clinician } \\
\text { observation }\end{array}$ & $\begin{array}{l}\text { Content validity assessed } \\
\text { as good by expert rating: } \\
\text { mean rating }=4.055 .0 \\
\text { Usefulness as an } \\
\text { cvaluative tool: mean } \\
\text { rating }=4.2 \\
\text { Further work in progress } \\
\text { Note: developers define } \\
\text { performance as what the } \\
\text { child does when } \\
\text { observed in the clinic, } \\
\text { which equates to } \\
\text { capability by our } \\
\text { lerminology }\end{array}$ & $\begin{array}{l}\text { Clinician } \\
\text { observation of } \\
\text { capability }[1,2]\end{array}$ \\
\hline $\begin{array}{l}\text { Seated Postural } \\
\text { Control } \\
\text { Measure } \\
\text { (SPCM) (II) }\end{array}$ & Seating function & $\begin{array}{l}\text { Pustural } \\
\text { alignment }=22 \\
\text { items } \\
\text { Funetional } \\
\text { movements }= \\
12 \text { items }\end{array}$ & $\begin{array}{l}\text { 1-19 yrs of age } \\
\text { Neurologically } \\
\text { impaired }(n= \\
45)\end{array}$ & $\begin{array}{l}\text { Clinician } \\
\text { observation } \\
20 \text { min } \\
\text { 3- or 4-level } \\
\text { ordinal scale } \\
\text { for each item }\end{array}$ & $\begin{array}{l}\text { Report face validity but no } \\
\text { details of methodology } \\
\text { Reliability: interrater k } \\
\text { statisties; } 0.45 \text { for } \\
\text { alignment, and } 0.85 \text { for } \\
\text { function } \\
\text { Test-retest reported us 'r - } \\
0.35 \text { for alignment and } \\
0.29 \text { for function (poor) }\end{array}$ & $\begin{array}{l}\text { Clinician } \\
\text { observation of } \\
\text { capability [1.2] }\end{array}$ \\
\hline $\begin{array}{l}\text { Children's } \\
\text { Adaptive } \\
\text { Behavior } \\
\text { Checklist } \\
\text { (CABS) (14) } \\
\text { original ref. } \\
\text { cited } \\
\text { as (26) }\end{array}$ & $\begin{array}{l}\text { Adaptive behavior; } \\
\text { discriminative, } \\
\text { evaluative }\end{array}$ & $\begin{array}{l}5 \text { yubdomains: } \\
\text { language, } \\
\text { independent } \\
\text { function, family } \\
\text { role } \\
\text { performance, } \\
\text { economic } \\
\text { vocational } \\
\text { activity, and } \\
\text { socialization } \\
\text { Ordinal scale }\end{array}$ & $\begin{array}{l}\text { 5-11 yr olds } \\
\text { Developmentally } \\
\text { disabled }\end{array}$ & $\begin{array}{l}\text { Trained psycho. } \\
\text { educational } \\
\text { evaluator } \\
\text { Interview of } \\
\text { child } \\
45 \mathrm{~min}\end{array}$ & $\begin{array}{l}\text { According to Gowland } \\
\text { (14): } \\
\text { Excellent inter- and } \\
\text { adequate intrarater } \\
\text { reliability } \\
\text { Adequate conent, } \\
\text { construct, and criterion } \\
\text { validity }\end{array}$ & $\begin{array}{l}\text { Interview-administered } \\
\text { measure (not } \\
\text { clear whether } \\
\text { performance } \\
\text { or capability) } \\
\text { [2.11 or } 2.21]\end{array}$ \\
\hline
\end{tabular}


APPENDIX (Continued)

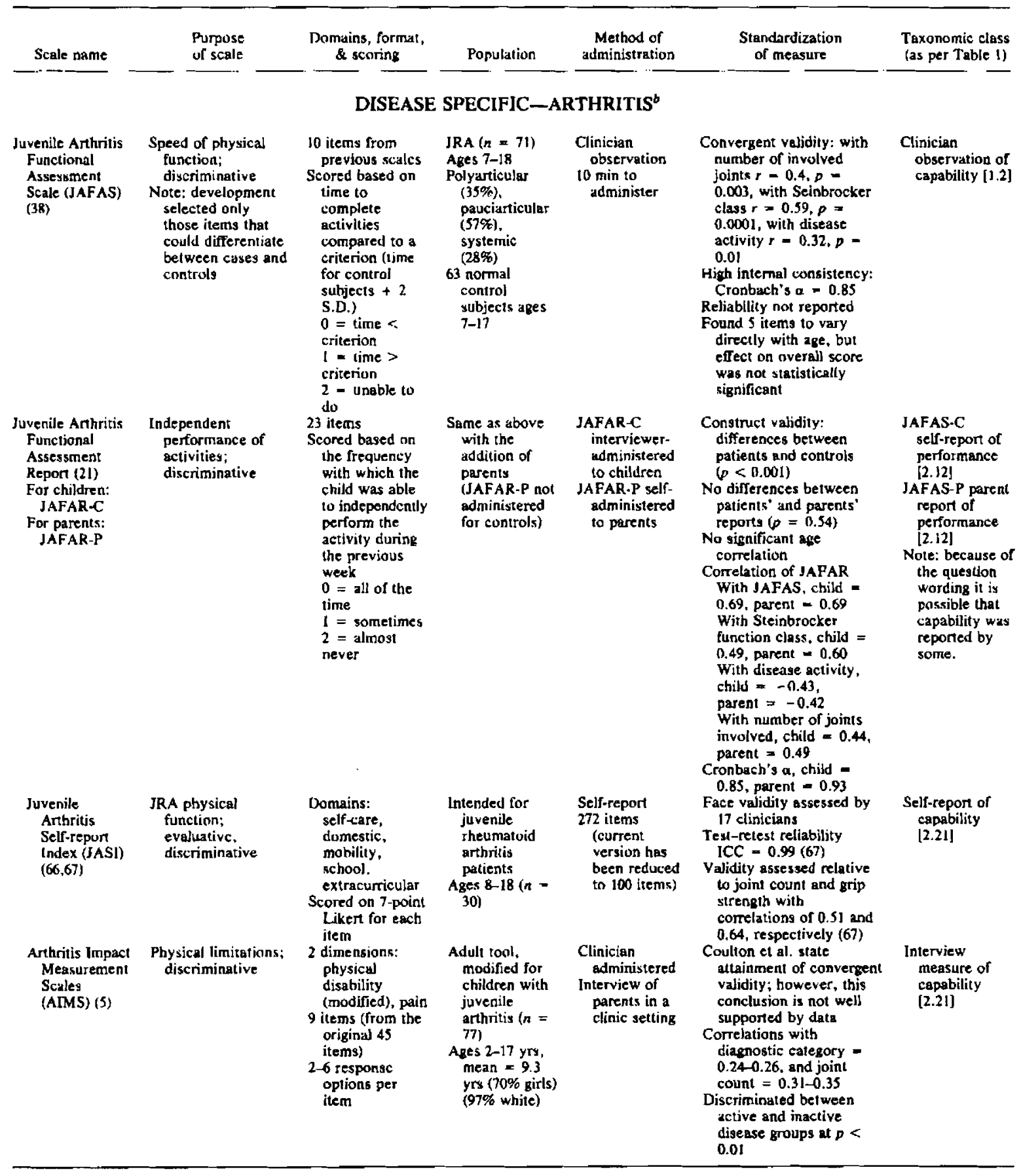

- See also WeeFIM, MCA, PEDI, TAMP, and COPM

- See also CHAQ and COPM. 